\title{
An Evaluation Studies On Construction Industry Marketization Degree
}

\author{
Zurong Chen \\ Business School, Hohai University, Nanjing \\ Jiangsu, 211100,China ; Institute of Project \\ Management of Hohai University, Nanjing Jiangsu, \\ 211100 China;Sinohydro bureau 16 company limited, \\ Fuzhou, 350003 China \\ E-mail: wangyuting2017@163.com
}

\author{
Jingchun Feng \\ Business School, Hohai University, Nanjing \\ Jiangsu,211100,China; Jiangsu Provincial Collaborative \\ Innovation Center of World Water Valley and Water \\ ecological civilization, Nanjing Jiangsu,211100 China ; \\ Institute of Project Management of Hohai University, \\ Nanjing Jiangsu, 211100 China \\ E-mail: feng.jingchun@163.com
}

\author{
Chunyan Xie \\ Business School, Hohai University, Nanjing \\ Jiangsu, 211100,China ; Institute of Project \\ Management of Hohai University, Nanjing Jiangsu, \\ 211100 China \\ E-mail: 451937780@qq.com
}

\author{
Chuanbin Zheng \\ Business School, Hohai University, Nanjing \\ Jiangsu, 211100,China ; Institute of Project \\ Management of Hohai University, Nanjing Jiangsu, \\ 211100 China \\ E-mail: 601741488@qq.com
}

\begin{abstract}
Based on the characteristics of construction industry, through the analysis of the object and subject of construction industry, the environment and regulation of the construction industry, the construction industry marketization evaluation index system is set up. The entropy weight method can be used to build and analyze the construction industry marketization evaluation model. The result shows that the construction industry marketization degree is $35.10 \%$. The degree is low and it means that the market belongs to the middle transition of market economy. It's necessary to build open and orderly market environment while strengthen the industry quality supervision ability to speed up the marketization process of construction industry.
\end{abstract}

Keywords-construction industry; marketization; degree evaluation Introduction ; Construction Indicators

\section{FOREWORD}

In China, the construction industry is always the largest resources consumer with the most output value. Meanwhile, it's also with the most serious planned economy feature and the lowest marketization degree. On July 8, 2014, "Several opinions about the promotion of the development and reform of construction industry", a document put forward by Ministry of Housing and UrbanRural Development first came up with the guiding idea that the market determined the resource allocation. It well defined the goal of streamline administration and delegate power, also the goal of establish a unified, open market system. It requested the reinforcement of the project quality and safety management, plus the transition of construction industry development way. The construction industry has already in an important period of the whole transformation accompanying by the progress of the concept of green culture, the upgrade of production technology, and the development of operation management methods. The present low construction industry marketization degree and the obvious objective problems existing in the market need to be urgently solved.

\section{MARKET RESEARCH STATUS}

The relationship between government and market has three basic ideas. Generally speaking, it includes the government-oriented type, the market-oriented type and the combination of two of them. The early economists like Adam Smith claim that the infrastructure construction is the government and the country's functions[1]. Keynes, on the other hand, stresses that the involvement of government is not only the need of politics, but also an necessary strategy for the economic development[2]. However, most recent development economist like Rostow maintain the leading role of government in the infrastructure construction. They claim that it's the way to realize economic development and to realize the social fairness. The reason of these is that the infrastructure is the condition of social transformation, productivity development and economic growth[3]. Although Hirschman does agree with this, he stress the market mechanism more[4]. Sasvas (2002) studies the positioning on the roles and functions of government, and he concludes that the new idea is based on the realization of government failure, the all-dimensional retreat of the government, the return of the market value and the marketization of the public service[5].

In recent years, the studies related to the relationship between the government and the market in infrastructure field is expanding. It involves many aspects such as privatization, relaxation on the government regulation, the reinforcement in the regulation of monopoly industries. In 1994, the world bank's annual development report concludes the reason of low efficiency of infrastructure in developing countries, commercial means, privatisation 
way and other aspects. It also analyses the marketability of the infrastructure products and services. The result is that except the urban road and urban drainage, all the other infrastructure has the possibility to be fully or partially marketized[6]. John R.Meyer(1993) studies the development rule of public utility and then he puts forward the theory of public utility privatization[7]. Berg Elliot(1993) analyses the infrastructure privatization and then comes with the idea that market-incentive mechanism is an efficient way to improve the efficiency of enterprise management[8].Dengshulian(2003) thinks that the reason why infrastructure field has mass privatization is that it has many problems like the need for funding, technological progress and cost-aimed price reform. She also does the empirical analysis about the effect of the infrastructure privatization and finds that is very obvious[9]. Huoyanjie(2003) thinks that the public utility reform will be lead to the trend of system reform and marketing allocates resources will be put in more important position. He also discusses the process of the marketization of the urban public utility and points out that the essence is to realize the basic role of market mechanism in public utility resources arrangement. This mainly includes the diversification of investors, the operator's enterprise and the marketization of the price formation and also the legalization of market regulation law[10]. Xiawenwu(2011)studies the problem in government monopoly of public goods supply, the possibility of market orientated supply of public utility, the inherent basis and conditions. He also studies the role and function of the government in this process and put forward that the fully use of market mechanism is very essential to solve the problem above[11].

Many scholars also discusses about the marketization degree evaluation. Gaojianren(2004)builds the index system of urban infrastructure marketization index and the evaluation model of marketization degree. In his theory, he pinpoints the degree and range of urban infrastructure products' or services' marketization. Moreover, he also defines the function range of government and market. He builds the structure system of the urban infrastructure marketization 's operation mechanism and explains its essence and feature[12]. Liutianjun, Houjunqi, Feizhenguo(2013) built agricultural infrastructure projects' marketization index model, and based on that, they position the investment bodies of 8 agricultural infrastructure. The result is that the enterprises and farmers should be the investor of the project with high infrastructure marketization and the government should be the investor of the project with general infrastructure marketization. Besides this, the private department can also join the investment. For the project with low marketization, the investor should be the government[13]. Songweiwei(2004) analyzed the order of the present construction market and he defines the index system of construction market evaluation and also raises the results[14]. Dengrui(2012) and Sunwanjuan(2013) constructed the index system of visible construction market evaluation[15, 16].Chenzhongfu(2001), Matianshan(2008),Wangfanji(2009) and Zoupeng(2012) built the index system of road transport market level measurement[17-20].

\section{TO BUILD THE EVALUATION INDEX SYSTEM OF CONSTRUCTION MARKETIZATION DEGREE}

\section{A. The overall plan of index system building}

From the definition of construction markets, it can be seen that the construction market is mainly involved in construction market main body, object and market environment. Therefore, the analysis and evaluation of the construction marketization degree should start with the specific situation of the three main elements.

Construction market includes a wide variety of market factors, and they are quite different. In order to evaluate the construction marketization degree, it sets up a group of interrelated indicators, and builds a complete evaluation system. These indicators must be able to reflect the operation state of all market elements form the microeconomic activity levels, while reflecting the acceptance and compliance between construction-related laws and regulations and all kinds of rules and public habits.

According to analyzing the current situation of construction market research, with reference to a large number of literature reading and questionnaire survey, through induction and analysis, the building marketoriented degree evaluation index system is divided into four categories: the subject index, market object market, market environment and market regulation index. The decomposition of different level index could further get the secondary indexes of the construction market, it forms a specific evaluation index system of construction market.

\section{B. The main index of construction market}

The construction market main body is the actors of the trading activities of the construction market. The market main body refers to the owners, construction companies, consulting firms, etc. The evaluation of market main body includes three aspects: First, all economic efficiency achieved by all market main body of the construction market in the current construction market in China can be analyzed through related industry-wide economic efficiency indicators; second, does it have appropriate conditions be related with the construction economic activities? As well as compliance with the conditions and qualifications required by relevant laws and regulations? For construction companies and intermediary consulting engineering companies, the main is whether they have the human condition, capital requirements commensurate with their economic activity, and whether they have the legal qualification, whether lawfully carried out the relevant registration procedures to obtain the corresponding qualifications; third, whether the internal governance structure of all types market main body of construction is adopted to market demand in the construction industry should be considered. .

The main indicators of the construction market includes the economic indicators of market main body, market indicators, the market access indicators of market main body, the market withdrawal of market main body and market governance structure, a total of 4 secondary indicators.

(1) Economic efficiency indicators. it Includes the construction total output, the construction industry production value and profit margin, the construction 
industry total annual profits and taxes three financial indicators.

(2) Market access indicators. It Includes number of new qualification of construction enterprises, number of new personal qualification certificate 2 indicators.

(3) Market withdraw indicators. It Includes cancellation or reducing the number of qualification of construction enterprises, the number of the personal qualification certificate of cancellation, cessation of use, relegated 2 indicators.

The access and withdraw of the market main body reflects the liquidity and dynamism of the construction market.

(4) Market governance structure. It reflects the enterprise's internal governance, including institutional integrity, good foundation, operating autonomy 3 indicators.

\section{The construction market object index}

Market object, including the building of the construction market completes transactions of various products and services on the market. Market object index is divided into 2 buildings secondary indicators: indicators of construction engineering and project management indicators.

(1) indices of construction engineering includes quality product rate of construction engineering, engineering degree of functional goals, quality public complaints each year, these 3 indicators reflect usage after the project is completed.

(2) project management indicators include management (agent), owner satisfaction, implementation project manager system. Among them, delegate management consists of the agent. Project Manager system is imported from abroad for the project management system, Project Manager responsibility, rights and benefit of great relationships. Implementation project manager system reflects the architecture degree in marketing, and in areas with a high degree of marketization, project manager system applications mature, while in areas where market imperfections, the project manager often becomes a mere formality.

\section{The construction market indicators}

Market environment is the object of market players and market and external factors. Market environment is the principal objective conditions beyond the control of the market, always in the midst of change. Marketplace changes with potential market opportunities may also be a threat. Market evaluation to examine market market activity in the construction market of objective conditions, the emphasis lies in the openness and fairness of the market.

Environmental indicators divided into market behavior in the market of the construction market indicators, market indicators, market indicators of regulatory and market barriers 4 secondary indicators.

(1) construction market indicators. Behavior refers to the construction market to enhance market power in the market, get taken advantage of strategies and actions, industrial enterprises in the various decisions taken. General including three aspects of content: $a$ is to control and effects price for basic features and purposes of pricing (quotes) behavior, including price competition and price coordination; II is to improve visibility, and expanded market share, and implementation integration operating, obtained high of profit for main content of non-price behavior; three is to found rent, for main features of not due competition behavior,. Construction market activity indicators are divided into price competition and non price competition and unfair competition. Price competition acts, including lower prices and dianzi construction; includes acts of non-price competition to improve quality, shorten the construction period, integration management, technological innovation, advertising and so on; acts of unfair competition, including collusion, conspiracy and round the mark, rent and so on.

(2) the specification of the construction market indicators. Reflects the order of the construction market, protect the legitimate rights and interests of market players, mainly from the offence rate in the construction industry, the construction project contract disputes, construction number measured proportion of arrears of three.

(3) building barriers to market indicators. Market barriers from the perspective of enterprises to enter the market adjustment and change of market relations, construction companies have been investigated and prepare to enter the enterprise's competitive relationship is reflected in the potential competition in the market. Market barriers include barriers to entry, the mobile barriers and exit barriers. Barriers to entry refers to a construction company to enter a market to engage in business activities needed to overcome the obstacles and the costs, barriers to entry level depends on the intensity of competition in the industry. Architectural barriers to market entry refers to the enterprise within the construction industry to prepare and just entering the industry the advantages of new businesses. In other words, preparing and entering new businesses in competition with existing enterprises in the construction industry in the process, may experience adverse factors, obstacles. Barriers to entry in determining the number and size distribution plays a key role in, but more importantly, it can also greatly affect the market power of incumbent firms (that is, the difference between the market price is higher than the cost), and become an essential condition for exercising market power. Moving between the barriers of entry and exit barriers, enterprises in the same industry from one segment to another segment of the market barriers encountered by mobile barriers are the main factors internal form separate markets. Exit barriers means a construction enterprises in the market pulled out of a building to overcome the obstacles and the costs, regulation and sunk costs such as human barriers. Low exit barriers of the industry reduces the pressure of excessive competition and the industry tide of inferior quality, which is of great significance.

\section{E. The construction market regulatory indicators}

Construction market means market supervision and management. Strictly speaking, construction Administrative Department for supervision of the construction market, is only one of construction market supervision, and government regulation of the situation in our country is to manage more than authority. In addition to relevant government authorities outside, the building market is still going to be trade associations, news media, even extensive oversight of the whole society. 
Building market regulatory indicators can be divided into such categories as the regulatory basis of mode indicators, monitoring indicators and monitoring indicators for these 3 secondary indexes.

(1) construction market supervision according to the index. Through a series of management systems and management program to ensure regulatory activities in line with national policies, laws and regulations, construction market supervision according to the index, including its basis of timeliness and completeness, its basis of supervision based on the suitability.

(2) construction market supervision mode indicator. Be considered from two aspects of government regulation and supervision, the construction market supervision mode indicators are divided into Government set reasonable, third-party organization (industry associations, NGO) and the degree of public concern. Government regulators set reflects the Government regulation of the market, thirdparty organization (industry associations, NGO) role and the degree of public concern reflected the role of the market.

(3) construction market supervision of performance indicators. Through quality accident rate, accident rate in the construction industry and construction market supervision's bad behavior 3 indicators to evaluate the effectiveness of market supervision.

The exact composition of each index of the construction market is shown in Table 1.

\section{F. Analysis of the construction market-oriented indicators}

Most of the indicators of construction market-oriented assessment system difficult to quantify, quantified indicators in the statistical are difficult to obtain. Therefore, this paper uses expert evaluation method to evaluate the construction market-oriented indicators. The indicators are divided into 5 levels; degrees from high to low are value of 5 points, 4 points, 3 points, 2 points and 1 point. This paper analyses some of the research situation of building enterprises, making the research more accurate.The evaluation criterion of the construction market-oriented indicators is shown in Table 1.

\section{COMPREHENSIVE EVALUATION OF CONSTRUCTION MARKET}

\section{A. Evaluation Model for the degree of Construction marketing Based on Entropy}

To carry on construction market evaluation, it is necessary to consider the views of relevant experts, to combine the inherent properties of the indicators. This article use evaluation methods based on the entropy theory with the combination of subjective and objective, making the evaluation results more reasonable.

In thermodynamics, entropy cannot be used to do work in the heat, and the mathematical expression is the quotient derived from the variation of heat divided by temperature. In information theory, entropy is a measure of the degree of disorder in the system, and the absolute value of the number and degree of ordering metric system is equal, while the direction of these two value is opposite.

Entropy method is a multi-target, multi-index comprehensive evaluation based primarily on objective information to evaluate almost unchecked or subjective factors, which largely avoids the interference of human factors, improving the evaluation of scientific.

$R^{\prime}$ is composed of $\mathrm{m}$ evaluation objects and $\mathrm{n}$ evaluation indexes:

$$
R^{\prime}=\left[\begin{array}{cccc}
r_{11}^{\prime} & r_{12}^{\prime} & \cdots & r_{1 n}^{\prime} \\
r_{21}^{\prime} & r_{22}^{\prime} & \cdots & r_{2 n}^{\prime} \\
\vdots & \vdots & \ddots & \vdots \\
r_{m 1}^{\prime} & r_{m 2}^{\prime} & \cdots & r_{m n}^{\prime}
\end{array}\right]
$$

Evaluation indicators of construction marketing degree have both efficiency indexer and cost-based indexes. For ease of analysis, it is necessary to normalize each index to prevent the poor conversion that the efficiency index is minimum, the maximum cost index is zero, improving poor conversion formula is adopted:

For the efficiency indicators:

$$
r_{i j}=\frac{r_{i j}^{\prime}-\operatorname{Min}_{i}\left(r_{i j}^{\prime}\right)}{\left(\operatorname{Max}_{i}\left(r_{i j}^{\prime}\right)-\operatorname{Min}_{i}\left(r_{i j}^{\prime}\right)\right) d_{1}}+d_{2}
$$

For the cost-based indicators:

$$
r_{i j}=\frac{\operatorname{Max}_{i}\left(r_{i j}^{\prime}\right)-r_{i j}^{\prime}}{\left(\operatorname{Max}_{i}\left(r_{i j}^{\prime}\right)-\operatorname{Min}_{i}^{\prime}\left(r_{i j}^{\prime}\right)\right) d_{1}}+d_{2}
$$

$r_{i j}$ is normalized to get the discrete distribution value ${ }^{f_{i j}}$ :

$$
f_{i j}=\frac{r_{i j}}{\sum_{i=1}^{m} r_{i j}}
$$

The relative entropy of evaluation index $\mathrm{j}$ :

$$
H_{j}=-k \sum_{i=1}^{m} f_{i j} \cdot \ln f_{i j}
$$

Among them: $k=\frac{1}{\ln m}$

$\mathrm{J}$-th index of entropy can be defined as:

$$
\omega_{j}=\frac{1-H_{j}}{\sum_{j=1}^{n}\left(1-H_{j}\right)}=\frac{1-H_{j}}{n-\sum_{j=1}^{n} H_{j}}
$$

In extreme cases, one entropy index reaches a maximum value 1 , the entropy is 0 , which means that the index does not provide any useful information so that it can be ruled out. In other words, the smaller the entropy is, the less important the index is.

$0 \leq \omega_{j} \leq 1$ 和 $\sum_{j=1}^{n} \omega_{j}=1$

Thus, the entropy only shows the indicator's relative degree of importance in the sense of competition .

According to the subjective evaluation of subjective weighting of the index $\lambda_{j}^{\prime}$, calculating indicators and integrated weights:

$\lambda_{j}=\frac{\lambda_{j}^{\prime} \omega_{j}}{\sum_{j=1}^{n} \lambda_{j}^{\prime} \omega_{j}}$

According to the right for the practical value ${ }^{\lambda_{j}}$ of the construction marketing degree evaluation index, evaluation value ${ }^{y_{i}}$ is calculated from each expert: 


$$
Y=R \lambda=\left[\begin{array}{cccc}
r_{11} & r_{12} & \cdots & r_{1 n} \\
r_{21} & r_{22} & \cdots & r_{2 n} \\
\vdots & \vdots & \ddots & \vdots \\
r_{m 1} & r_{m 2} & \cdots & r_{m n}
\end{array}\right]\left[\begin{array}{c}
\lambda_{1} \\
\lambda_{2} \\
\vdots \\
\lambda_{n}
\end{array}\right]
$$

The larger the evaluation value ${ }^{y_{i}}$ is, the higher the degree of the construction market is. Based on standards of the degree of marketing, most scholars have stressed that there is no $100 \%$ in the market, but it is agreed to all that $0 \%$ should be taken as a complete program of standards in order to define the full $100 \%$ of the market. At present, the marketing metrics is mainly treated with qualitative and quantitative degree of marketing. It can be classified as following: market at $0-15 \%$ for the non-market economy, $10 \%-30 \%$ for the weak economy, $30 \%-50 \%$ for mediumterm market economy transition, $50 \%-65 \%$ for late transition economy, 65\%-80\% for underdeveloped market economy or relatively mature market economies, above $80 \%$ for the developed market economies, or mature market economies. Construction marketing metrics also uses these criteria in this paper.

\section{B. valuation of the construction degree of marketization}

With the above model to calculate the weight of each indicator, as is shown in Table 1.

TABLE I. THE EVALUATION CRITERION OF THE CONSTRUCTION MARKET-ORIENTED INDICATORS AND THE INDEX WEIGHT OF THE DEGREE OF CONSTRUCTION MARKETIZATION

\begin{tabular}{|c|c|c|c|c|}
\hline $\begin{array}{c}\text { first } \\
\text { level } \\
\text { indicat } \\
\text { ors }\end{array}$ & $\begin{array}{l}\text { secon } \\
\mathrm{d}- \\
\text { level } \\
\text { indica } \\
\text { tors }\end{array}$ & $\begin{array}{l}\text { Three } \\
\text { indicators }\end{array}$ & Evaluation Criteria & $\begin{array}{l}\text { Th } \\
\text { e } \\
\text { we } \\
\text { ig } \\
\text { hts }\end{array}$ \\
\hline \multirow{6}{*}{$\begin{array}{c}\text { Buildi } \\
\text { ng } \\
\text { Market } \\
\text { Princip } \\
\text { al } \\
\text { Parts } \\
\left(X_{1}\right. \\
\text { ) }\end{array}$} & \multirow{3}{*}{$\begin{array}{c}\text { econo } \\
\text { mic } \\
\text { benefi } \\
t \\
(\mathrm{~A} \\
)\end{array}$} & $\begin{array}{l}\text { gross product } \\
\text { of construction } \\
\text { industry } \\
\left(\mathrm{A}_{1}\right)\end{array}$ & $\begin{array}{c}\text { Very High }=5 \text { 、 } \\
\text { High }=4 、 \text { General } \\
=3 、 \text { Low }=2 、 \text { Very } \\
\text { Low }=1\end{array}$ & $\begin{array}{c}0 . \\
00 \\
78\end{array}$ \\
\hline & & $\begin{array}{l}\text { Output in the } \\
\text { construction } \\
\text { industry profit } \\
\text { margin }\left(\mathrm{A}_{2}\right)\end{array}$ & $\begin{array}{c}\text { Very High }=5 \text { 、 } \\
\text { High }=4 、 \text { General } \\
=3 、 \text { Low }=2 、 \text { Very } \\
\text { Low }=1\end{array}$ & $\begin{array}{c}0 . \\
12 \\
68\end{array}$ \\
\hline & & $\begin{array}{l}\text { The total } \\
\text { profits of } \\
\text { construction } \\
\text { enterprises } \\
\left(\mathrm{A}_{3}\right)\end{array}$ & $\begin{array}{l}\text { Growing very fast } \\
=5 、 \text { Growing fast } \\
=4 、 \text { General growth } \\
=3 、 \text { Growing slow } \\
=2 、 \text { Growing very } \\
\text { slow }=1\end{array}$ & $\begin{array}{c}0 . \\
00 \\
78\end{array}$ \\
\hline & \multirow{2}{*}{$\begin{array}{c}\text { marke } \\
\mathrm{t} \\
\text { access } \\
(\mathrm{B} \\
)\end{array}$} & $\begin{array}{c}\text { Number of } \\
\text { added } \\
\text { qualification of } \\
\text { construction } \\
\text { enterprises } \\
\left(\mathrm{B}_{1}\right)\end{array}$ & $\begin{array}{c}\text { Very much =5、 } \\
\text { Much =4、General } \\
=3 、 \text { Little }=2 、 \\
\text { Very little }=1\end{array}$ & $\begin{array}{c}0 . \\
01 \\
41\end{array}$ \\
\hline & & $\begin{array}{l}\text { Number of } \\
\text { new personal } \\
\text { qualification } \\
\text { certificate } \\
\left(\mathrm{B}_{2}\right)\end{array}$ & $\begin{array}{c}\text { Very much =5、 } \\
\text { Much }=4 、 \text { General } \\
=3 、 \text { Little }=2 、 \\
\text { Very little }=1\end{array}$ & $\begin{array}{c}0 . \\
01 \\
27\end{array}$ \\
\hline & $\begin{array}{c}\text { marke } \\
\text { t exit } \\
(\mathrm{C} \\
)^{\prime}\end{array}$ & $\begin{array}{l}\text { the number of } \\
\text { construction } \\
\text { enterprises } \\
\text { suspend or }\end{array}$ & $\begin{array}{c}\text { Very much }=5 \text { 、 } \\
\text { Much }=4 、 \text { General } \\
=3 、 \text { Little }=2 、 \\
\text { Very little }=1\end{array}$ & $\begin{array}{c}0 . \\
00 \\
68\end{array}$ \\
\hline
\end{tabular}

\begin{tabular}{|c|c|c|c|c|}
\hline & & $\begin{array}{l}\text { reduced the } \\
\text { qualification } \\
\left(\mathrm{C}_{1}\right)\end{array}$ & & \\
\hline & & $\begin{array}{l}\text { the number of } \\
\text { private practice } \\
\text { qualification } \\
\text { certificates of } \\
\text { Revocation, } \\
\text { suspension, } \\
\text { demotion using } \\
\text { (C2) }\end{array}$ & $\begin{array}{c}\text { Very much }=5 、 \\
\text { Much }=4 、 \text { General } \\
=3 、 \text { Little }=2 、 \\
\text { Very little }=1\end{array}$ & $\begin{array}{l}0 . \\
00 \\
73\end{array}$ \\
\hline & \multirow{3}{*}{$\begin{array}{l}\text { gover } \\
\text { nance } \\
\text { struct } \\
\text { ure } \\
\text { (D } \\
\text { ) }\end{array}$} & $\begin{array}{l}\text { System } \\
\text { integrity } \\
\left(D_{1}\right)\end{array}$ & $\begin{array}{l}\text { Very perfect }=5 、 \\
\text { Perfect }=4 、 \text { General } \\
=3 、 \text { Imperfect }=2 、 \\
\text { Very imperfect }=1\end{array}$ & $\begin{array}{l}0 . \\
01 \\
27\end{array}$ \\
\hline & & $\begin{array}{l}\text { Basic work } \\
\text { integrity } \\
\left(D_{2}\right)\end{array}$ & $\begin{array}{l}\text { Very perfect }=5 \text { 、 } \\
\text { Perfect }=4 、 \text { General } \\
=3 、 \text { Imperfect }=2 、 \\
\text { Very imperfect }=1\end{array}$ & $\begin{array}{l}0 . \\
01 \\
91\end{array}$ \\
\hline & & $\begin{array}{l}\text { Operating } \\
\text { autonomy } \\
\quad\left(D_{3}\right)\end{array}$ & $\begin{array}{l}\text { Very independent } \\
=5 、 \text { Independent } \\
=4 、 \text { General }=3 \text { 、 } \\
\text { Dependent }=2 、 \\
\text { Very dependent }=1\end{array}$ & $\begin{array}{l}0 . \\
01 \\
06\end{array}$ \\
\hline \multirow{6}{*}{$\begin{array}{l}\text { Object } \\
\text { of } \\
\text { constr } \\
\text { uction } \\
\text { market } \\
\quad\left(X_{2}\right. \\
)^{2}\end{array}$} & \multirow{3}{*}{$\begin{array}{l}\text { constr } \\
\text { uction } \\
\text { projec } \\
\mathrm{t} \\
(\mathrm{E} \\
)^{2}\end{array}$} & $\begin{array}{l}\text { Rate of } \\
\text { construction } \\
\text { project quality } \\
\text { product }\left(\mathrm{E}_{1}\right)\end{array}$ & $\begin{array}{c}\text { Very High }=5 、 \\
\text { High }=4 、 \text { General } \\
=3 、 \text { Low }=2 、 \text { Very } \\
\text { Low }=1\end{array}$ & $\begin{array}{l}0 . \\
00 \\
78\end{array}$ \\
\hline & & $\begin{array}{c}\text { Degree of } \\
\text { engineering } \\
\text { functional aims } \\
\text { achieved } \\
\left(E_{2}\right)\end{array}$ & $\begin{array}{c}\text { Completely } \\
\text { achieved =5、 nearly } \\
\text { achieved =4、 } \\
\text { General =3、 } \\
\text { Incompletely } \\
\text { achieved }=2 、 \text { not } \\
\text { achieved }=1\end{array}$ & $\begin{array}{l}0 . \\
00 \\
04\end{array}$ \\
\hline & & $\begin{array}{l}\text { Annual } \\
\text { number of } \\
\text { public } \\
\text { complaints } \\
\text { against the } \\
\text { quality of the } \\
\text { project }\left(\mathrm{E}_{3}\right)\end{array}$ & $\begin{array}{c}\text { Very much =5、 } \\
\text { Much }=4 、 \text { General } \\
=3 、 \text { Little }=2 、 \\
\text { Very little }=1\end{array}$ & $\begin{array}{l}0 . \\
00 \\
54\end{array}$ \\
\hline & & $\begin{array}{l}\text { Proportion of } \\
\text { entrusted } \\
\text { management } \\
\text { (including } \\
\text { Agent System) } \\
\quad\left(\mathrm{F}_{1}\right)\end{array}$ & $\begin{array}{c}\text { Very High }=5 、 \\
\text { High }=4 、 \text { General } \\
=3 、 \text { Low }=2 、 \text { Very } \\
\text { Low }=1\end{array}$ & $\begin{array}{l}0 . \\
03 \\
32\end{array}$ \\
\hline & $\begin{array}{c}\text { projec } \\
\mathrm{t} \\
\text { mana } \\
\text { geme } \\
\mathrm{nt} \\
(\mathrm{F})\end{array}$ & $\begin{array}{c}\text { Owner } \\
\text { satisfaction } \\
\left(\mathrm{F}_{2}\right)\end{array}$ & $\begin{array}{c}\text { Very satisfied }=5 \text { 、 } \\
\text { Satisfied }=4 、 \\
\text { General }=3 \text { 、 } \\
\text { Dissatisfied }=2 、 \\
\text { Very dissatisfied }=1\end{array}$ & $\begin{array}{l}0 . \\
00 \\
78\end{array}$ \\
\hline & & $\begin{array}{l}\text { Implementatio } \\
\mathrm{n} \text { of project } \\
\text { manager } \\
\text { system }\left(\mathrm{F}_{3}\right)\end{array}$ & $\begin{array}{c}\text { fully equipped }=5 \text { 、 } \\
\text { Basically equipped } \\
=4 、 \text { General }=3 、 \\
\text { Basically } \\
\text { unequipped }=2 、 \\
\text { Unequipped }=1\end{array}$ & $\begin{array}{l}0 . \\
01 \\
27\end{array}$ \\
\hline $\begin{array}{c}\text { Buildi } \\
\text { ng } \\
\text { market }\end{array}$ & $\begin{array}{c}\text { marke } \\
\mathrm{t} \\
\text { activit }\end{array}$ & $\begin{array}{c}\text { Price } \\
\text { competition } \\
\left(\mathrm{G}_{1}\right)\end{array}$ & $\begin{array}{c}\text { Very serious }=5 、 \\
\text { Serious }=4 、 \\
\text { General }=3 、 \text { Less }\end{array}$ & $\begin{array}{l}0 . \\
00 \\
68\end{array}$ \\
\hline
\end{tabular}




\begin{tabular}{|c|c|c|c|c|}
\hline \multirow{9}{*}{$\begin{array}{l}\text { enviro } \\
\text { nment } \\
\left(X_{3}\right. \\
)\end{array}$} & \multirow{3}{*}{$\begin{array}{l}y \\
(G\end{array}$} & & $\begin{array}{c}\text { serious }=2 \text { 、 Not } \\
\text { serious }=1\end{array}$ & \\
\hline & & $\begin{array}{l}\text { Non-price } \\
\text { competition } \\
\quad\left(G_{2}\right)\end{array}$ & $\begin{array}{c}\text { Very serious }=5 \text { 、 } \\
\text { Serious }=4 、 \\
\text { General }=3 、 \text { Less } \\
\text { serious }=2 、 \text { Not } \\
\text { serious }=1\end{array}$ & $\begin{array}{l}0 . \\
01 \\
91\end{array}$ \\
\hline & & $\begin{array}{c}\text { Unfair } \\
\text { competition } \\
\left(\mathrm{G}_{3}\right)\end{array}$ & $\begin{array}{c}\text { Very serious }=5 \text { 、 } \\
\text { Serious }=4 、 \\
\text { General }=3 、 \text { Less } \\
\text { serious }=2 、 \text { Not } \\
\text { serious }=1\end{array}$ & $\begin{array}{l}0 . \\
03 \\
94\end{array}$ \\
\hline & \multirow{3}{*}{$\begin{array}{l}\text { Mark } \\
\text { et } \\
\text { standa } \\
\text { rd } \\
(\mathrm{H} \\
)^{\prime}\end{array}$} & $\begin{array}{c}\text { Penalties for } \\
\text { violations Rate } \\
\left(\mathrm{H}_{1}\right)\end{array}$ & $\begin{array}{c}\text { Very High }=5 、 \\
\text { High }=4 、 \text { General } \\
=3 、 \text { Low }=2 、 \text { Very } \\
\text { Low }=1\end{array}$ & $\begin{array}{l}0 . \\
00 \\
54\end{array}$ \\
\hline & & $\begin{array}{l}\text { Number of } \\
\text { construction } \\
\text { project } \\
\text { contract } \\
\text { disputes } \\
\left(\mathrm{H}_{2}\right)\end{array}$ & $\begin{array}{c}\text { Very much }=5 、 \\
\text { Much }=4 、 \text { General } \\
=3 、 \text { Little }=2 、 \\
\text { Very little }=1\end{array}$ & $\begin{array}{l}0 . \\
03 \\
94\end{array}$ \\
\hline & & $\begin{array}{l}\text { The proportion } \\
\text { of construction } \\
\text { arrears }\left(\mathrm{H}_{3}\right)\end{array}$ & $\begin{array}{c}\text { Very High }=5 、 \\
\text { High }=4 、 \text { General } \\
=3 、 \begin{array}{l}\text { Low }=2 、 \text { Very } \\
\text { Low }=1\end{array}\end{array}$ & $\begin{array}{l}0 . \\
03 \\
21\end{array}$ \\
\hline & \multirow{3}{*}{$\begin{array}{l}\text { Mark } \\
\text { et } \\
\text { barrie } \\
\text { rs } \\
\text { (I) }\end{array}$} & $\begin{array}{l}\text { Barriers to } \\
\text { market entry } \\
\qquad\left(\mathrm{I}_{1}\right)\end{array}$ & $\begin{array}{c}\text { Very High }=5 、 \\
\text { High }=4 、 \text { General } \\
=3 、 \begin{array}{c}\text { Low }=2 、 \text { Very } \\
\text { Low }=1\end{array}\end{array}$ & $\begin{array}{l}0 . \\
01 \\
27\end{array}$ \\
\hline & & $\begin{array}{l}\text { Market mobile } \\
\text { barriers }\left(\mathrm{I}_{2}\right)\end{array}$ & $\begin{array}{c}\text { Very High }=5 \text { 、 } \\
\text { High }=4 、 \text { General } \\
=3 、 \text { Low }=2 、 \text { Very } \\
\text { Low }=1\end{array}$ & $\begin{array}{l}0 . \\
01 \\
27\end{array}$ \\
\hline & & $\begin{array}{r}\text { Market exit } \\
\text { barriers }\left(\mathrm{I}_{3}\right)\end{array}$ & $\begin{array}{c}\text { Very High }=5 、 \\
\text { High }=4 、 \text { General } \\
=3 、 \text { Low }=2 、 \text { Very } \\
\text { Low }=1\end{array}$ & $\begin{array}{l}0 . \\
03 \\
32\end{array}$ \\
\hline \multirow{5}{*}{$\begin{array}{l}\text { constr } \\
\text { uction } \\
\text { market } \\
\text { superv } \\
\text { ision } \\
\left(\mathrm{X}_{4}\right. \\
)^{2}\end{array}$} & \multirow{3}{*}{$\begin{array}{l}\text { Basis } \\
\text { of } \\
\text { Mark } \\
\text { et } \\
\text { Super } \\
\text { vision } \\
(\mathrm{J})\end{array}$} & $\begin{array}{l}\text { Integrity of } \\
\text { Regulatory } \\
\text { basis }\left(\mathrm{J}_{1}\right)\end{array}$ & $\begin{array}{l}\text { Very perfect }=5 、 \\
\text { Perfect }=4 、 \text { General } \\
=3 、 \text { Imperfect }=2 、 \\
\text { Very imperfect }=1\end{array}$ & $\begin{array}{l}0 . \\
01 \\
06\end{array}$ \\
\hline & & $\begin{array}{l}\text { The timeliness } \\
\text { of regulatory } \\
\text { basis }\left(\mathrm{J}_{2}\right)\end{array}$ & $\begin{array}{c}\text { Very timely }=5 \text { 、 } \\
\text { Timely }=4 、 \text { General } \\
=3 \text { 、Untimely }=2 \text { 、 } \\
\text { Very untimely }=1\end{array}$ & $\begin{array}{l}0 . \\
01 \\
06\end{array}$ \\
\hline & & $\begin{array}{c}\text { The } \\
\text { applicability of } \\
\text { the regulatory } \\
\text { basis }\left(\mathrm{J}_{3}\right)\end{array}$ & $\begin{array}{c}\text { Very applicable } \\
=5 、 \text { Applicable } \\
=4 、 \text { General =3、 } \\
\text { Not applicable =2、 } \\
\text { Very not applicable } \\
=1\end{array}$ & $\begin{array}{l}0 . \\
01 \\
41\end{array}$ \\
\hline & \multirow{2}{*}{$\begin{array}{c}\text { Mark } \\
\text { et } \\
\text { super } \\
\text { vising } \\
\text { patter } \\
\text { n } \\
\text { ( K } \\
\text { ) }\end{array}$} & $\begin{array}{l}\text { The rationality } \\
\text { of government } \\
\text { supervision } \\
\text { department } \\
\left(\mathrm{K}_{1}\right)\end{array}$ & $\begin{array}{c}\text { Very } \\
\text { reasonable }=5 \text { 、 } \\
\text { Reasonable =4、 } \\
\text { General =3、 } \\
\text { Unreasonable }=2 \text { 、 } \\
\text { very unreasonable }=1 \\
\end{array}$ & $\begin{array}{l}0 . \\
00 \\
78\end{array}$ \\
\hline & & $\begin{array}{l}\text { The role of the } \\
\text { third party } \\
\text { organization }\end{array}$ & $\begin{array}{c}\text { Very obvious }=5 \\
\text { Obvious }=4 、 \\
\text { General }=3 、\end{array}$ & $\begin{array}{l}0 . \\
28 \\
04\end{array}$ \\
\hline
\end{tabular}

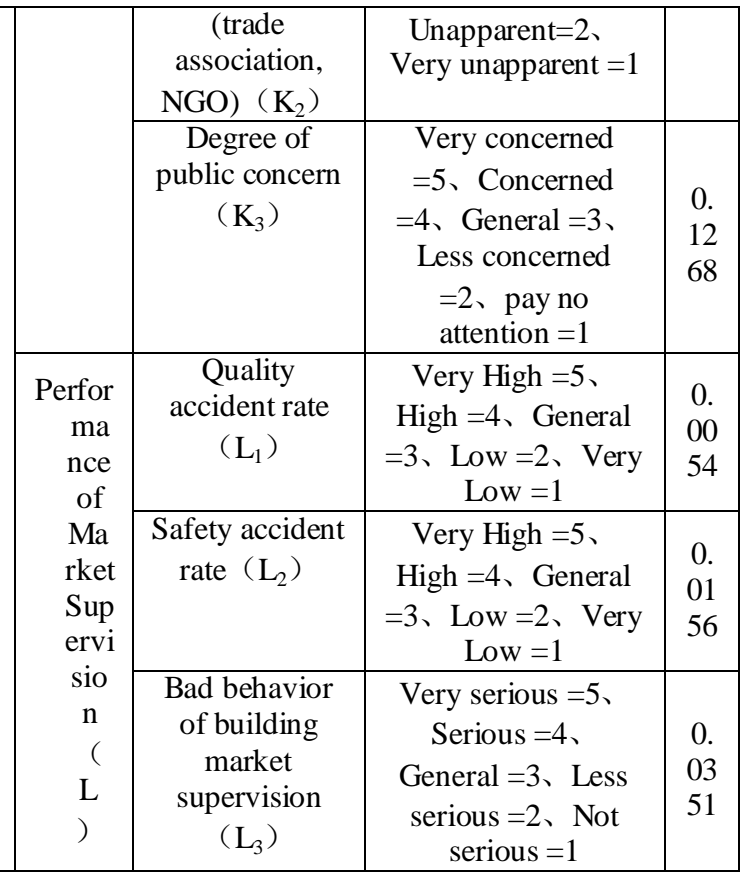

After obtaining the weights of each index, obtain the evaluation results of the construction marketization degree from each expert by formula (9). It is believed that these experts are neutral judge who do not have clear preference or tendency and give the same weight to every expert, thus obtained experts on the construction of a the degree of marketization indicators and comprehensive evaluation of the value of the evaluation results.

According to evaluation results, the degree of the construction market is $35.10 \%$, where the degree of the main body construction marketization is $9.11 \%$, objects of the degree of construction marketization is $3.81 \%$, the degree of construction environment marketization is $8.88 \%$, the degree of construction marketization regulation is $13.29 \%$, belonging to the mid-the market economic transition, which describes the lower degree of the construction market. Construction industry has entered an important stage in the overall restructuring and development, but the current level of construction market is low. Only the establishment of an open and orderly market environment and strengthen the capacity of industry quality control can promote the transformation and upgrading of construction and speed up the process of construction market.

\section{ACKNOWLEDGMENT}

This work was supported by The National Social Science Fund (Key Project of the 2012, Grant No. 14AZD024):The innovation of mechanism of Public Private Partnership under the financial support in the field of infrastructure.; the Fundamental Research Funds for the Central Universities (2013/B14020090): The decision mechanism of Public Private Partnership under the financial support in the field of large-scale infrastructure.

\section{REFERENCES}

[1] Adam Smith. the study of the nature and causes of the wealth of Nations. Beijing: commercial press 1979.

[2] Keynes. the general theory of employment, interest and money. Beijing. the commercial press in 1988 . 
[3] the Rostow. from takeoff into sustained growth in the boardroom. Chengdu. Sichuan people's publishing house, 1988.

[4] aiboteheximan. Pan Zhaodong, translated. the strategy for the economic development. Beijing. Economic Science Press, 1991.

[5] Savvas. translation of Zhou Zhi ren. the privatization and publicprivate sector partnership. Beijing. people's University Press 2002.

[6] Kessides,Christine.1993a, The Contribution of Infrastructure to Economic Development: A Review of Experience and Policy Implications. Word Bank Discussion Paper 213.Washington D.C.

[7] Jose Gomez-Ibanez and John R.Meyer, Going Private: The International Experience with Transport-Privatization (Washington, D.C.: Brookings Institution,1993)

[8] Berg, Elliot.1993. Privatization in Sub-Saharan Africa: Results, Prospects, and New Approaches. Bethesda, Md.: Development Alternatives

[9] Deng Shulian. the infrastructure of public policies in China., Shanghai Shanghai finance and Economics University Press 2003.

[10] Huo Yanjie. Reflection on marketization of urban public utilities industry. the China construction news. 2003 No. 3171, 4th Edition.

[11] the summer mo. Marketization of public goods market as a case study of Shaoxing city infrastructure $[\mathrm{J}]$. Business Economics, 2011,9:140-143.
[12] the GAO Jian people. Research on the market operation mechanism of urban infrastructure [D]. Chongqing University PhD thesis, 2004.

[13] Liu Tianjun, and Hou Junqi, and Fei Zhenguo. Investment in agricultural infrastructure projects subject index of location-based marketing model of quantitative analysis [J]. Journal of Huazhong agricultural University (Social Science Edition), 2012,6:15-19.

[14] the song great. Analysis and evaluation on construction market order [D]. Master's degree thesis at Tsinghua University, 2004.

[15] Deng Rui. Tangible building market index system [D]. Wuhan University of technology master's degree thesis, 2012.

[16] Sun Wanjuan. based on the SCP paradigm of tangible building market evaluation index system's construction [d]. Wuhan University of technology master's degree thesis, 2013.

[17] chenzhong Fu. Discussion on marketization of automobile transportation [J]. an integrated transport, 2001 (5)

[18] horse tianshan. study on the evaluation index system of road transport market [J]. an integrated transport, 2008.09

[19] Wang fanji, and Ma Deke. analysis and advice level of road transportation market in Gansu Province [J]. Western traffic technology, 2009.11

[20] Zou Peng. road passenger transport market construction and empirical analysis of measurement method of [D]. Chang ' an University Master's degree thesis, 2012. 